\title{
UDC 621.039
}

Yu. Komarov ${ }^{1}$, DSc,

A. Arvaninov ${ }^{2}$,

A. Smychok ${ }^{1}$

${ }^{1}$ Separated subdivision “Scientific and Technical Center” of the State Enterprise “National Nuclear Energy Generating Company “Energoatom”, 63 a Khmelnytskogo Str., Kyiv, Ukraine, 02217; e-mail: ontps@i.ua

${ }^{2}$ Separate subdivision of "South-Ukrainian NPP" of the State Enterprise "National Nuclear Energy Generating Company "Energoatom” e-mail: ontpo@i.ua

\section{IMPROVEMENT OF THE ALGORITHM}

\author{
FOR THE CALCULATION OF THE AVERAGE
}

\author{
WEIGHTED THERMAL POWER OF THE VVER-1000 \\ CORE AND THE ESTIMATION OF ITS ERROR
}

\begin{abstract}
Ю.О. Комаров, О.Л. Арванінов, А.А. Смичок Удосконалення алгоритму розрахунку середньозваженого значення теплової потужності активної зони ВВЕР-1000 і оцінка його похибки. Вимірювання теплової потужності активної зони реактора (Ак3) на атомних електростанціях (АЕС) з водо-водяним енергетичним реактором електричною потужністю 1000 MBT (BВEР1000) можна характеризувати як непрямі, нерівноточні, незалежні. Представлено аналіз п'яти існуючих способів оцінки теплової потужності АкЗ. Показана існуюча проблема оцінки точності отримання середньозваженого значення теплової потужності (СЗТП) Ак3. Оцінка значення СЗТП АкЗ є найкращою оцінкою з одержуваному ряду (з п'яти значень) теплової потужності АкЗ. При цьому оцінки вагового коефіцієнта кожного вимірювання пов'язані з оцінкою похибки даного виміру. Чим вище точність методу, тим вище вага даної оцінки. Представлено аналіз методики оцінки теплової потужності АкЗ, реалізований в програмній частині системи внутрішньореакторного контролю (СВРК) ВВЕР-1000. Показано, що для практичного використання для оцінки теплової потужності АкЗ на АЕС з ВВЕР-1000 облік всіх класів і видів похибки можливий коректної оцінкою двох складових - випадкова і систематична похибка. При цьому облік обох складових похибки (випадкової і систематичної) є обов'язковим. Розроблено методику, яка враховує такі основні аспекти: по кожному прямому вимірюванню (тиск, температура, тощо) оцінюється як сама величина, так і її похибка; для кожного (з п'яти) способів вимірювання теплової потужності АкЗ на підставі функціональних залежностей і похибки прямих вимірювань проводиться оцінка похибки непрямого вимірювання даної теплової потужності; проводиться оцінка вагових коефіцієнтів кожного способу вимірювання за величиною похибки непрямого вимірювання теплової потужності АкЗ; оцінка абсолютної похибки середньозваженого значення потужності проводиться за методикою оцінки точності для непрямих вимірювань. В результаті, існуючий на АЕС алгоритм СВРК доповнено розрахунковими залежностями для оцінки похибки СЗТП АкЗ і розрахунками похибки всіх складових, необхідних для розрахунку СЗТП. Представлені шляхи модифікації існуючого в СВРК алгоритму і уточнення константної бази даних СВРК для підвищення точності оцінки СЗТП АкЗ.

Ключові слова: теплова потужність, похибка, середньозважене значення, ВВЕР, СВРК
\end{abstract}

Yu. Komarov, A. Arvaninov, A. Smychok. Improvement of the algorithm for the calculation of the average weighted thermal power of the VVER-1000 core and the estimation of its error. Measurements of the thermal power of the reactor core (RC) at nuclear power plants (NPP) with a water-cooled power reactor with an electrical capacity of 1000 MW (VVER-1000) can be characterized as indirect, unequal and independent. An analysis of the five existing methods for estimating the thermal power of RC is presented. The existing problem of estimating of the error of the average weighted thermal power (AWTP) of RC is shown. Estimation of the AWTP value is the best estimate for the resulting series (out of five values) of the thermal power of the RC. In this case, the estimates of the weight coefficient of each measurement are associated with an estimate of the error of this measurement. If we have the higher accuracy of the method to we have the higher weight of this assessment. The analysis of the thermal power rating of the RC which is implemented in the system of in-core monitoring system (SVRK) of VVER-1000 is presented. It is shown that for practical use for estimating the thermal power of the RC at a NPP with a VVER-1000, taking into account all classes and types of error is possible with a correct assessment of two components - random and systematic error. In this case, the account of both components of errors (random and systematic) is mandatory. Developed a technique that takes into account the following main aspects: for each direct measurement (pressure, temperature, etc.), both the magnitude and its error are estimated; for each (out of five) methods of measuring the thermal power of RC, based on the functional dependences and the error of direct measurements, an estimate of the error of indirect measurement of this thermal power is carried out; assessment of the weighting coefficients of each measurement method is carried out by the magnitude of the error of indirect measurement of the thermal power of RC; the estimation of the absolute error of the weighted average power value is carried out according to the method for assessing the accuracy for indirect measurements. As a result, the SVRK algorithm which existing at NPPs was supplemented with calculated dependencies for estimating the error of the AWTP of RC and calculations of the error of all components necessary for the calculation of the AWTP. The ways of modification of the algorithm existing in the SVRK and specification of the constant database of the SVRK are presented to improve the accuracy of the estimation of the AWTP of RC.

Keywords: thermal power, error, weighted average, VVER, SVRK

DOI: 10.15276/opu.1.57.2019.09

(C) 2019 The Authors. This is an open access article under the CC BY license (http://creativecommons.org/licenses/by/4.0/). 
Introduction. The thermal power level of the reactor core (RC) is one of the main parameters by which the limits and conditions for the safe operation of the reactor are established. Also RC thermal power level is the main parameter for assessing of technical and economic parameters of power unit operation.

At VVER power units, the determination of the reactor thermal power and its operational control are carried out with the help of a standard in-core monitoring system (SVRK).

In practice, the thermal power of the reactor core (RC) cannot be directly measured. Therefore, the value of thermal power is determined by calculation (that is, by an indirect method of measurement) using mathematical processing of direct thermophysical measurements and indirect neutron-physical calculations carried out using special algorithms in the SVRC as well as with the help of a computer with the reduction of the heat balance between the first and the second circuits of the reactor facility.

The SVRK in terms of thermal power control should provide the operating personnel of the reactor unit and to the adjacent control and management reactor systems with the most reliable value of the $\mathrm{RC}$ thermal power. This value is taken as the average weighted value of the thermal power $\left(N_{R C}\right)$, which is calculated in the SVRC using the power values obtained using five $(n=5)$ independent nonequal-level methods [1]:

1. On the parameters of the first circuit $-N_{1 C}$;

2. On the parameters of the second circuit - taking into account the flow of feed water in steam generators $(\mathrm{SG})-N_{S G}$;

3. On the parameters of the second circuit - taking into account the feedwater consumption by the high-pressure heaters $(\mathrm{HPH})-N_{\mathrm{HPH}}$;

4. According to indications of ionization chambers (IC) of the neutron flux monitoring equipment (NFMS) $-N_{I C}$

5. According to the readings of emission sensors, which are also called direct charge detectors (DCD) $-N_{D C D}$.

The weighted average of the thermal power (AWTP) of the core is necessary to establish the most probable power value of these five measurement methods. This value should be as close as possible to the estimate of the actual value, minimally vary over time in stationary modes. It is also necessary to note that the use of $N_{R C}$ is necessary to exclude the apparent distortion of the thermal power of the reactor installation in cases of unreliable measurement result obtained by the $i$-th measurement method.

In this case, both the RC AWTP itself and its error are important. The error in determining $N_{R C}$ is crucial in justifying the allowable values of maintaining maximum reactor power. So, the increase in thermal power of reactors of operating units with VVER-1000 to $101.5 \% N_{\text {nom }}$ is expected due to the implementation of a set of works on improving the accuracy of determining of reactor power and increasing the accuracy of controlling power of the reactor [2, 3].

Analysis of recent publications and problem statement. In order to establish a unified approach, the methods for determining the RC AWTP used in the SVRK, as well as the methods of determining the weighted average used in metrology and in other measurement areas were analyzed [4 - 6].

It is considered which of the calculation methods is acceptable, as far as the use of one or another calculation method brings the weighted average value to the actual value. We also analyzed acceptable approaches to determine the weighted average value of the thermal power of the reactor unit VVER-1000.

A qualitative and quantitative analysis of the algorithm for calculating of the RC AWTP existing in the SVRK is presented. The error of calculating this value is estimated. Ways of modifying the algorithm are outlined to reduce the error of the RC thermal power estimate [7, 8].

According to the results of the analysis, it has been established that today there is no single standardized approach for calculating the weighted average (obtained in several ways) values of the thermal power of the core and its error; therefore, it is relevant to establish a single approach to determine these values.

The purpose and objectives of the study. The purpose of this work is to substantiate the method for determining the weighted average of the thermal power of the VVER-1000, which approximates the weighted average to the actual value with acceptable accuracy. 
Objectives of the study:

1. Calculation (if necessary) and error analysis of independent methods for determining the thermal power of the reactor.

2. Collection and analysis of the methodological basis for determining the weighted average of the thermal power and its error, used in the VVER-1000 SVRK, as well as the methods of determining the weighted average used in metrology and in other measurement areas.

3. Selection and justification of an acceptable method for determining the weighted average value of thermal power and its error.

4. Estimated estimates of the weighted average value of thermal power and its error.

Theoretical approaches to the assessment and improvement of algorithms RC AWTP. When averaging a series of values, each of which differs in its significance (different error, reliability, relevance, quality, etc.), a so-called weighted average is used, in which each value of the data series is assigned its own weighting coefficient.

This approach is acceptable when averaging values that have different magnitudes of error.

Consider the following general case of estimating the weight coefficients for a number of independent non-equal-dimensional measurements. Let there be $n$ independent non-equal-dimensional measurements $x_{i}$, having absolute error $\Delta x_{i}, i=1, \ldots, n$.

The weighted average evaluation of such a series of measurements is:

$$
y=\frac{W_{1} \times x_{1}+W_{2} \times x_{2}+\ldots+W_{n} \times x_{n}}{W_{1}+W_{2}+\ldots+W_{n}},
$$

where $W_{i}$ - weight coefficient $i=1, \ldots, n$.

If the measurement data is independent, then the absolute error of the value of $y$ depending on the error of the measured values of $x_{i}$ in the general case has the form [9]:

$$
\Delta y=\sqrt{\left(\frac{\partial y}{\partial x_{1}}\right)^{2} \Delta x_{1}{ }^{2}+\ldots+\left(\frac{\partial y}{\partial x_{n}}\right)^{2} \Delta x_{n}{ }^{2}},
$$

where $\left(\frac{\partial y}{\partial x_{i}}\right)$ - partial derivative of $y$ for each of the variables $x_{i}, i=1, \ldots, n$;

$\Delta x_{i}$-absolute measurement error $x_{i}, i=1, \ldots, n$.

The partial derivatives for the functional dependence of the type of the weighted average (1) are:

$$
\left(\frac{\partial y}{\partial x_{i}}\right)=\frac{W_{i}}{W_{1}+W_{2}+\ldots+W_{n}}, \quad i=1, \ldots, n .
$$

Substituting (3) into (2) we obtain the expression for the absolute error of the weighted average value $y$ :

$$
\Delta y=\frac{\sqrt{W_{1}^{2} \Delta x_{1}^{2}+W_{2}^{2} \Delta x_{2}^{2}+\ldots+W_{n}^{2} \Delta x_{n}^{2}}}{W_{1}+W_{2}+\ldots+W_{n}} .
$$

With the help of weights $\left(W_{i}\right)$ it is possible to minimize the value of the error $\Delta y$.

We also find $W_{i}, i=1, \ldots, n$ for which the quantity $\Delta y$ takes the minimum value.

It can be shown that $\Delta y$ becomes minimal with the following optimal weights:

$$
W_{i}=\frac{m}{\left(\Delta x_{i}\right)^{2}}, \quad i=1, \ldots, n \text {. }
$$

where $m$ is any number greater than zero, the same for all $W_{i}$.

The last expression is of great practical importance, because:

1. Shows that the weight of the measurement result (when evaluating the weighted average) should be inversely proportional to the square of the measurement error; 
2. Perhaps an infinitely large number of optimal weights $W_{i}$, which will differ in the value of $m$. That is, it is important that the weights are multiples of each other in compliance with (5).

In particular, the optimal weights are the set of values (for $m=1$ ):

$$
W_{i}=\frac{1}{\left(\Delta x_{i}\right)^{2}}, \quad i=1, \ldots, n \text {. }
$$

Substituting (6) into (4), we obtain the minimum possible error of the weighted average (with optimally selected weights), which will be:

$$
\Delta y^{*}=\frac{1}{\sqrt{\Delta x_{1}^{-2}+\Delta x_{2}^{-2}+\ldots+\Delta x_{n}^{-2}}},
$$

Any other weights, other than those defined by (5), will lead to a higher error in the weighted average. The values of the weighted average error, determined with the weight coefficients for (5) and (6), as well as for any other $m>0$, will have the same value. The minimum value of the error y obtained using the optimal weights will be determined by the expression (7).

Let us analyze expression (7) from the point of view of the influence of individual errors of independent measurements $\Delta x_{i}, i=1, \ldots, n$. Based on the structure (7), important for practical application conclusion follows: the more measurement results cover the weighted average, the lower the error of this weighted average will be, while the weighted error will not be higher than the error of the most accurate measurement.

The presented conclusions and conclusions of the formulas are fully applicable to the solution of an applied problem of improving the estimates of the RC AWTP and its errors.

The weights for the existing five measurement methods will have optimal values for:

$$
W_{i}=\frac{1}{\left(\Delta N_{i}\right)^{2}}, \quad i=1, \ldots, 5,
$$

where $\Delta N_{i}$ - the absolute error in estimating the RC thermal power by the $i$-th measurement method.

It should be noted that when optimizing the weight coefficients, it is possible to use not the absolute errors of the estimates of the thermal power of the RC $\left(\Delta N_{i}, i=1, \ldots, 5\right)$, but the corresponding relative errors $\left(\delta N_{i}, i=1, \ldots, 5\right)$. This replacement is possible, since the optimum is not at a point, but corresponds to the set of vectors $\left\{W_{1}, W_{2}, \ldots, W_{5}\right\}$, which differ in their multiplicity.

In the transition from absolute to relative error, this multiplicity is observed. Therefore, the optimal values of weight coefficients can also be calculated by the expression:

$$
W_{i}=\frac{1}{\left(\delta N_{i}\right)^{2}}, \quad i=1, \ldots, 5,
$$

where $\delta N_{i}$ - the relative error in estimating the RC thermal power by the $i$-th measurement method.

It should be noted that such methods for estimating the thermal power of RC as estimates for the parameters of SG and HPH are inertial. The measurements are delayed in the presence of a transient process with a change in power of the switchgear. The estimation method for the parameters of the 1st circuit has a smaller delay compared to the SG / HPH estimate; however, it also lags behind the dynamics-sensitive assessment methods NFMS for the ionization chambers and DCD readings.

Accounting for these effects is carried out either by cutting off inertial methods or through the introduction of the dynamic component of error.

In the case of cutting off the inertial estimation methods, the principles for calculating the weight coefficients do not change, but only the number of averaged estimation methods change ( $n$ becomes $<5$ ).

In the case of the use of the dynamic component of the error, it should be included as a term in the error by this method. Since the dynamic component does not depend on the instrumental component of the error, their addition is carried out as for uncorrelated random variables:

$$
\Delta N_{i}=\sqrt{\Delta N_{i n_{i}}^{2}+D_{i n_{i}}^{2}},
$$


where $\Delta N_{i}$ - the total error of the $i$-th method of estimating the thermal power of RC;

$\Delta N_{i n_{i}}$ - instrumental (random and systematic) error of the $i$-th method for estimating the thermal power of RC;

$D_{i n_{i}}$ - dynamic component of the error of the $i$-th method for estimating the thermal power of the RC.

Substituting (10) into (8), we obtain an expression for estimating the weight coefficients taking into account the dynamic component:

$$
W_{i}=\frac{1}{\Delta N_{i n_{i}}^{2}+D_{i n_{i}}^{2}},
$$

A certain problem is the coordination of dimensions of absolute values $\Delta N_{i n_{i}}$ and $D_{i n_{i}}$. Unambiguous approaches to the assessment of $D_{\text {in }}$ does not exist, but depending on the balance of the values of the quantities $\Delta N_{i n_{i}}$ and $D_{i n_{i}}$, it is possible that the contribution of one or another component to the resulting error is incorrectly taken into account.

Another feature of the algorithms that are used in practice is the use of constant weights instead of the current values of the error.

In the calculation algorithms of SVRK, there are two ways of estimating the RC AWTP - the main and the minor [1].

The main method of calculating the RC AWTP in detail in a simplified form can be described by the following calculated dependencies:

$$
N_{R C}=\frac{W_{1} N_{1}+W_{2} N_{2}+\ldots+W_{5} N_{5}}{W_{1}+W_{2}+\ldots+W_{5}},
$$

where $N_{1}, \ldots, N_{5}$ - thermal power of RC, estimated in one of five ways [MW];

$W_{1}, \ldots, W_{5}$ - weight coefficients determined taking into account the two components of the error (dimensionless quantity):

$$
W_{i}=\frac{1}{\left(\frac{x_{0 i}}{x_{i} k_{i}}\right)^{2}+D_{i n_{i}}{ }^{2}},
$$

where $k_{i}$ - weight constant, which is a reflection of the accuracy of the $i$-th method of estimating the thermal power of the RC (dimensionless quantity);

$\frac{x_{0_{i}}}{x_{i}}$ - the ratio, which for methods No. $1-3$ characterizes the change in error when the thermal power deviates from the nominal power, and for method No. 5, the accuracy deteriorates due to the failure (inaccurate readings) of some DCD;

$D_{i n_{i}}$ - dynamic component, which shows how the power of the $i$-th method deviated from the average value calculated at the same time point using low-inertia methods (a dimensionless quantity).

As mentioned above, this component is designed to reduce the weight of inertial methods of calculation (such as estimation of SG and HPH) in the conditions of the transition process.

In a simplified form, the calculation of the dynamic component is carried out as follows:

$$
D_{\text {ini }}=\frac{N_{\text {average }}-N_{i}}{S S}, \quad N_{\text {average }}=\frac{1}{3}\left(N_{1}+N_{4}+N_{5}\right),
$$

where $N_{1}, N_{4}, N_{5}$ - estimates of the thermal power of the RC for the parameters of the 1st circuit, RC NFMS, DCD, respectively [MW];

ss - a fixed value taken to be $30 \mathrm{MW}$ (half of the standard error at rated power).

The non-basic method of calculating the weighted average thermal power of the RC in a simplified form can also be represented by the calculated dependence (12) in which the weight coefficients are determined without taking into account the dynamic component. But then the analysis of all meth- 
ods for estimating the thermal power of the reactor core is carried out on the deviation from the weighted average value obtained.

In the non-basic method of calculating the weighted average thermal power of the RC, the weighting factors are calculated by the expression:

$$
W_{i}=\frac{x_{i}}{x_{0 i}} k_{i}
$$

where $x_{i} / x_{0_{i}}$ - the ratio, which for methods No. $1-3$ characterizes changes in the error when the thermal power deviates from the nominal power, and for method No. 5, the accuracy deteriorates due to the failure (inaccurate readings) of some DCD.

It should be noted that the coefficients $k_{i}$ in expressions (13) and (15) have a different physical meaning and must be calculated in various ways.

So $k_{i}$ in (13) is a coefficient reflecting the accuracy of the $i$-th measurement method, while:

$$
k_{i} \propto \frac{1}{\Delta N_{i}},
$$

The value of the coefficient $k_{i}$ in (15) is the value reflecting the values of the square of the accuracy of the $i$-th measurement method:

$$
k_{i} \propto \frac{1}{\left(\Delta N_{i}\right)^{2}} .
$$

Cutting off unreliable in terms of the dynamics of the process of estimating the thermal power of the RC in the non-basic method of estimating the AWTP is carried out in the case of a significant deviation of the results of the $i$-th method from the AWTP value.

After cutting off unreliable results of power estimates, the AWTP is recalculated.

In both methods of evaluation (main and non-core), RC AWTP has its pros and cons:

1. For both methods of assessment, the weighting factors contain a component of the $x / x_{0}$ type, which is not always justified;

2. The calculation of the dynamic component $D_{i n_{i}}$ in the basic method of calculation as a deviation from the average (taken only by methods $N_{1}, N_{4}, N_{5}$ ) can lead to significant jumps in the values of the dynamic component, especially when the values of $N_{1}, N_{4}, N_{5}$ are significantly different from each other. The discontinuous behavior of the weight coefficients $W_{i}$ in the basic method of calculation, in turn, will lead to constant jumps in the resulting error of the RC AWTP;

3. Exclusion of results for individual methods of calculation, firstly, reduces the accuracy of the weighted average, secondly, it can lead to a situation where all five methods for calculating the thermal power of RC are recognized and unreliable, which is basically unacceptable - this is a loss of indication of an important safety indicator.

Based on the analysis, the tasks are formed:

1. Carry out the calculation of the error of the RC AWTP for the nominal power level and for the transition process using the main and non-basic method of estimating the weighted average (using the algorithms existing in the SVRK and $k_{i}$ coefficients);

2. To clarify the coefficients $k_{i}$ for the main and non-basic method for estimating the RC AWTP (for the nominal power level and for the transient process);

3. To refine the algorithm for calculating the weights $W_{i}$.

Estimates and their analysis.

Calculations of RC AWTP and its errors for the nominal power level and for the actual transient process with a rise in power of the SUNPP Unit No. 1 were performed.

The considered transient process lasts for about 2 days (Fig. 1). In the first section (for about 4 hours), an increase in power is observed at a speed of about $4 \mathrm{MW} /$ minute. In the second area (for about 20 hours), a rise in power is observed with a slower speed - about $0.5 \mathrm{MW} /$ minute. Then there is a stay at the nominal power level - a stationary state for about 23 hours. 


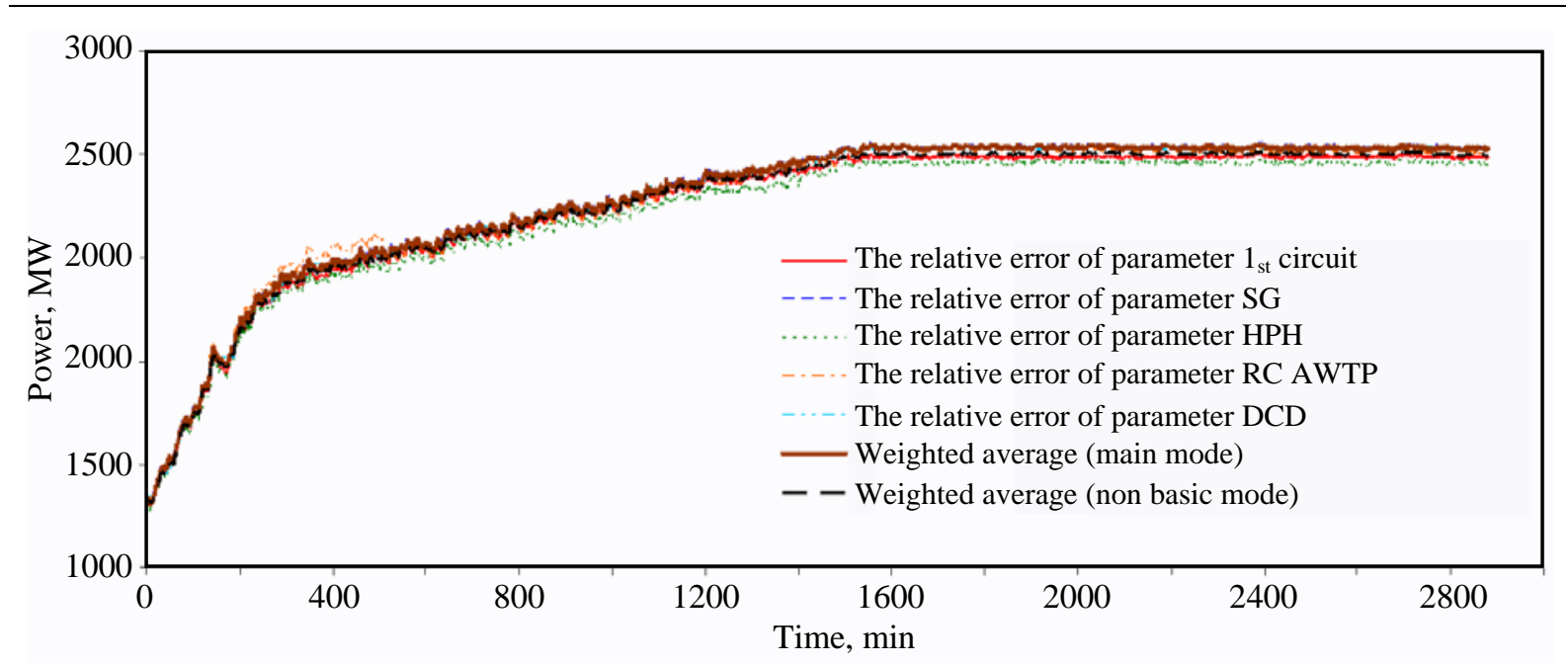

Fig. 1. Thermal power of $R C$

The absolute errors in estimating the thermal power of the RC increase as the RC power increases.

The relative error in estimating the thermal power of the RC, basically, either has a decreasing trend, or does not change as the power of the RC increases (Fig. 2).

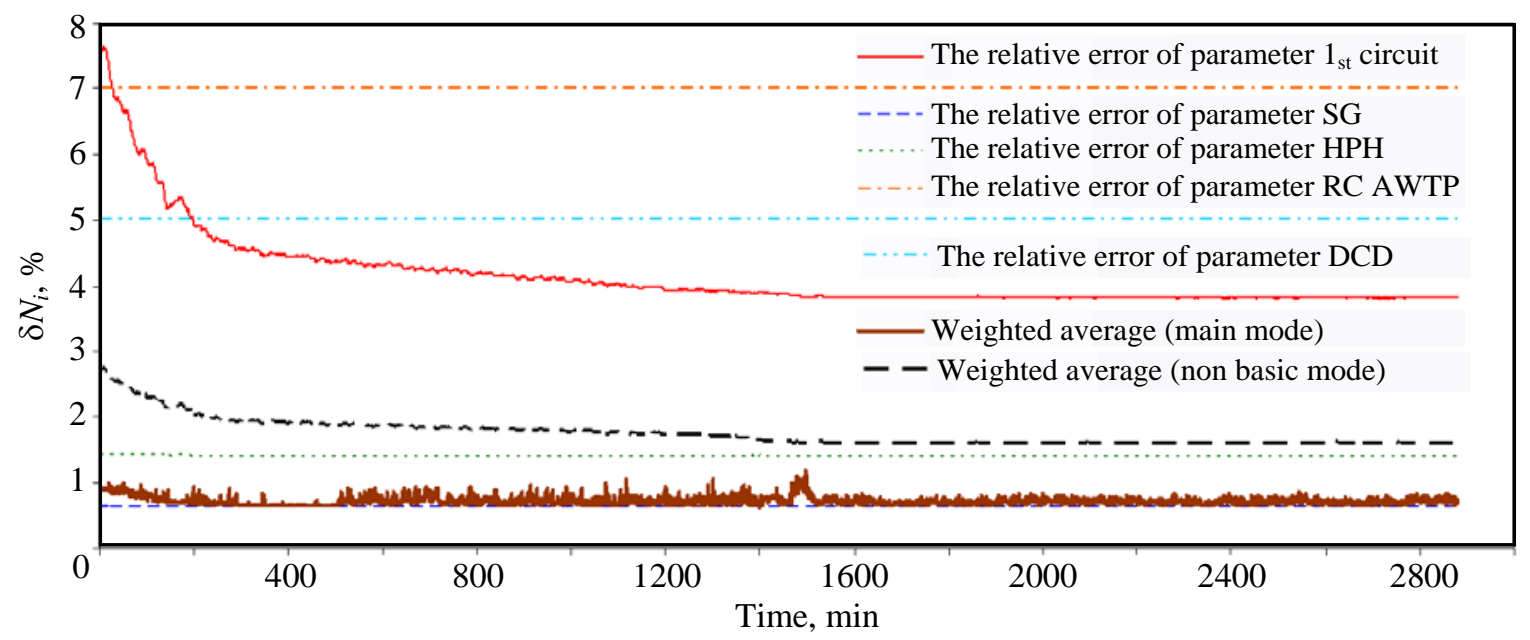

Fig. 2. Relative error of $R C$ thermal power (for the existing calculation algorithm and existing $k_{i}$ coefficients)

The calculations for the existing algorithms for calculating the RC AWTP and the existing coefficients $k_{i}$ show that for these conditions the main method for estimating the RC AWTP is more preferable, since it has a smaller calculation error than the non-basic method.

It should be noted that the results of the calculation for the main and non-basic methods for calculating the RC AWTP differ, with the difference in the estimates reaching $50 \mathrm{MW}$. This difference in the estimates is little dependent on the current capacity and is related to the error of estimates of the RC AWTP.

In Fig. 3 presents a comparison of the errors for the main and non-basic methods for estimating the RC AWTP. From the comparison follows:

1. The error values for the main method have a significant jump-like character, while the magnitude of the jumps in the absolute error can reach $15 \mathrm{MW}$ (or $0.5 \%$ in terms of the relative error;

2. The magnitude of the jumps (for the main method of evaluation) increases as the thermal power of the RC increases. 


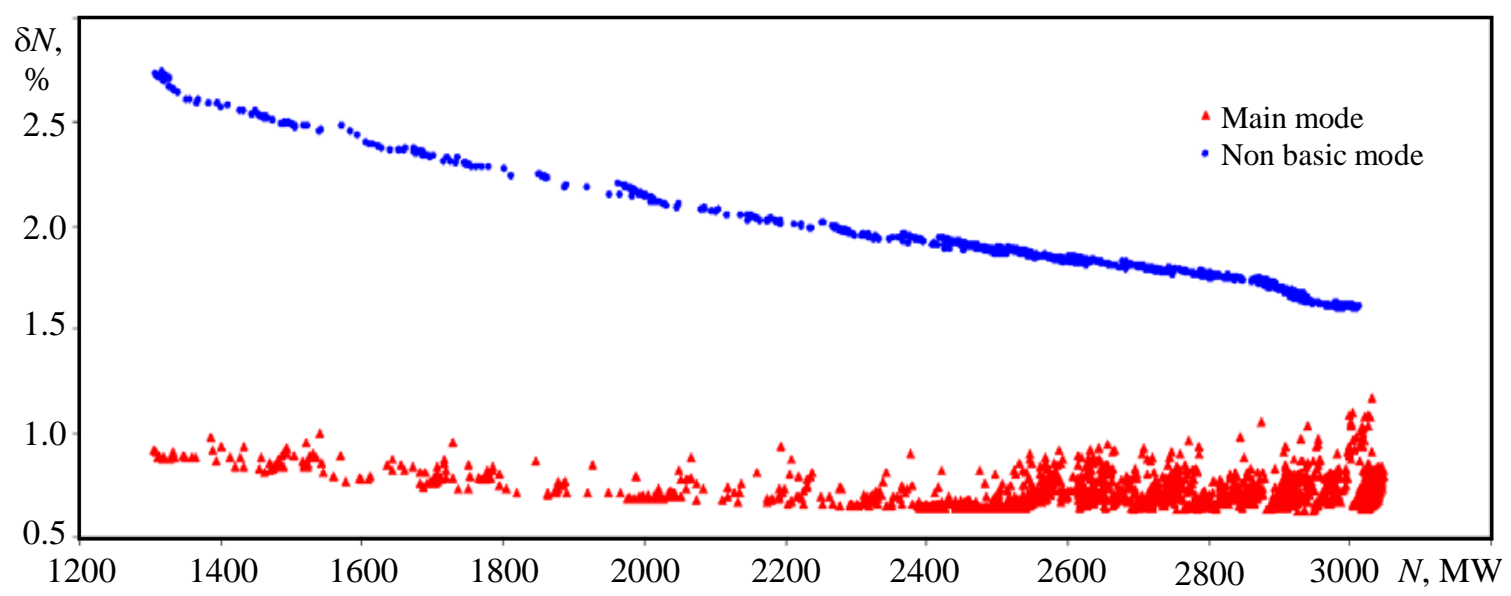

Fig. 3. Relative error of estimating the weighted average of the thermal power of the RC depending on the thermal power of the RC (for the existing calculation algorithm and the existing coefficients $k_{i}$ )

The presence of the discontinuous nature of the error of the RC AWTP is due to the peculiarities of the calculation of the weight coefficients $W_{i}$ (see expressions (13), (14)).

The calculated dependences for $W_{i}$ include the so-called dynamic component, whose behavior has a significant jump-like character. In this case, the absolute errors of the estimate can transform the values $D_{i n i}$ themselves. All this leads to the fact that the weight coefficients $W_{i}$ for the main method of calculating the weighted average have a significant stepwise character compared to the weight coefficients $W_{i}$ for the non-basic method of calculation. This is also reflected in the error in estimating $W_{i}$, which for the basic method of calculation reaches $200 \%$, and for the minor method - no more than $12.5 \%$.

The overall relative error of the weighted average for the main method of calculation is lower than for the minor one.

The easiest way to influence the error of the RC AWTP is to change the coefficients $k_{i}$, which in the algorithm existing in the SVRK are used to calculate the weight coefficients $W_{i}$.

The change in the values of $k_{i}$ is carried out by standard methods of changing the constant base of the SVRK.

The coefficients $k_{i}$ were optimized for both methods of calculating the RC AWTP, first for the nominal power (provided that all methods for estimating the thermal power give the same result of $3000 \mathrm{MW}$ ) and for the actual transient process with the power rise (Fig. 4).

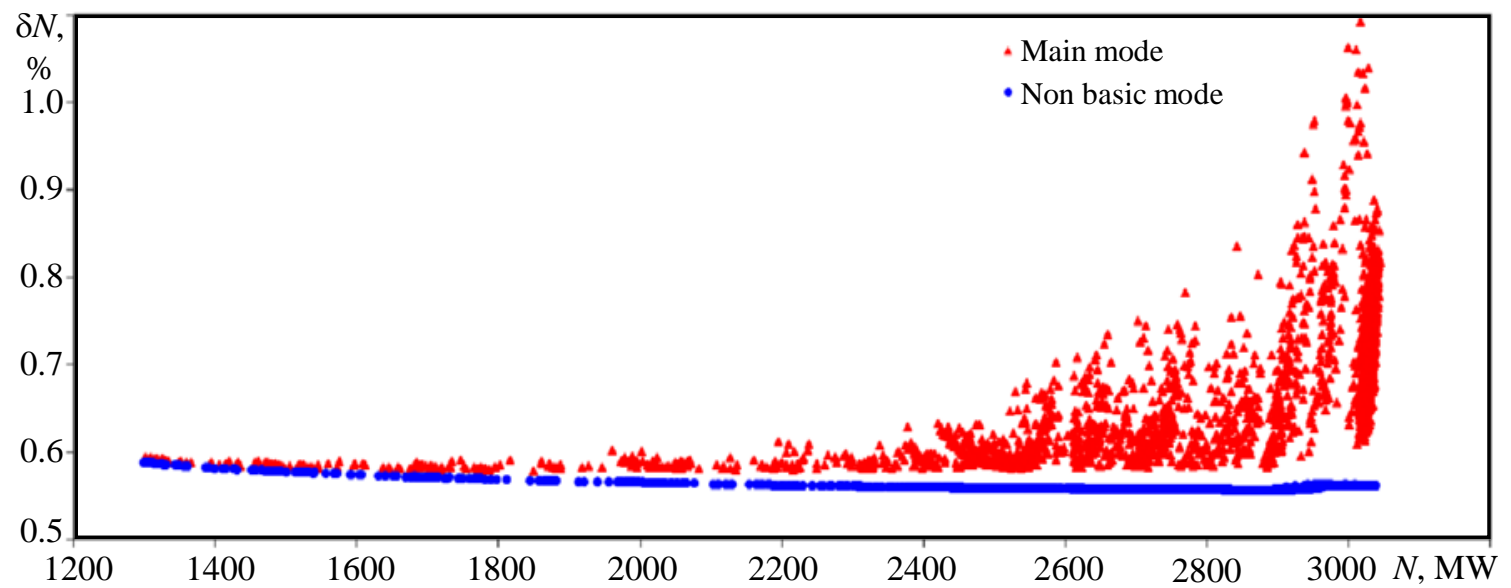

Fig. 4. Relative error of estimating the weighted average of the thermal power of the RC at the optimum $k_{i}$ (for the existing calculation algorithm) 
The results of calculations show that for the non-basic method of calculating the RC AWTP it is possible to achieve a significant reduction in the weighted error by applying the optimal values of the coefficients $k_{i}$. In this case, the error for the non-basic method of calculation becomes lower than the error of the basic method of calculation.

With an increase in the thermal power of the RC, the jumps in the error value increase. The discontinuous nature of the error of the basic method of calculation is associated with the presence of a dynamic component $D_{i n_{i}}$ in the formula for calculating the weight coefficients $W_{i}$.

The discontinuous nature of the error of the basic method of calculation, firstly, makes it impossible to unambiguously optimize the weight coefficients, and secondly, to the impossibility to exclude (with the help of $k_{i}$ optimization) a significant error in the results of the assessment of the RC AWTP.

During the transition from the main to the non-basic method of calculating the weighted average (using the optimal $k_{i}$ ), the maximum value of the relative error of the RC AWTP will not exceed $0.6 \%$ (both for the nominal, stationary power level and for the transient process).

However, with this approach, the estimate of the RC power will actually be estimated by the parameters of SG and HPH (the weight of these two RC power measurements is about $96 \%$ of the total weight of the weighted average). In case of a transient process with power imbalance, it is necessary to exclude inertial calculation methods (for SG and for HPH).

Exceptions of inertial methods are possible according to the algorithm used for the non-basic method of assessment - comparison of deviation $N_{i}$ and $\bar{N}_{C R}$ with the setpoint. In this case, $\bar{N}_{C R}$ it should be calculated using low-inertia methods.

Thus, the proposed modification of the existing non-basic algorithm for calculating the RC AWTP, which consists in the following (hereinafter referred to as Modification No. 1):

1 . An estimate is made of the average value of the thermal power of the RC according to $N_{1 C}$, $N_{R C}, N_{D C D}$ to obtain $N_{3 S}$;

2. The deviation of each power estimate from $N_{3 S}$ is checked. In case of a deviation of more than $2 \%$, this power estimate is excluded from consideration.

Deviations of any value by more than $2 \%$ are regarded as a possible beginning of the transition process.

Also, Modification No. 2 was proposed, which consists in changing the ratios characterizing the change in error when the thermal power of the RC deviates from the nominal one (see expression (13)).

From the calculations, it follows that Modification No. 2 has a slight positive effect, reducing the error of the RC AWTP (Fig. 5).

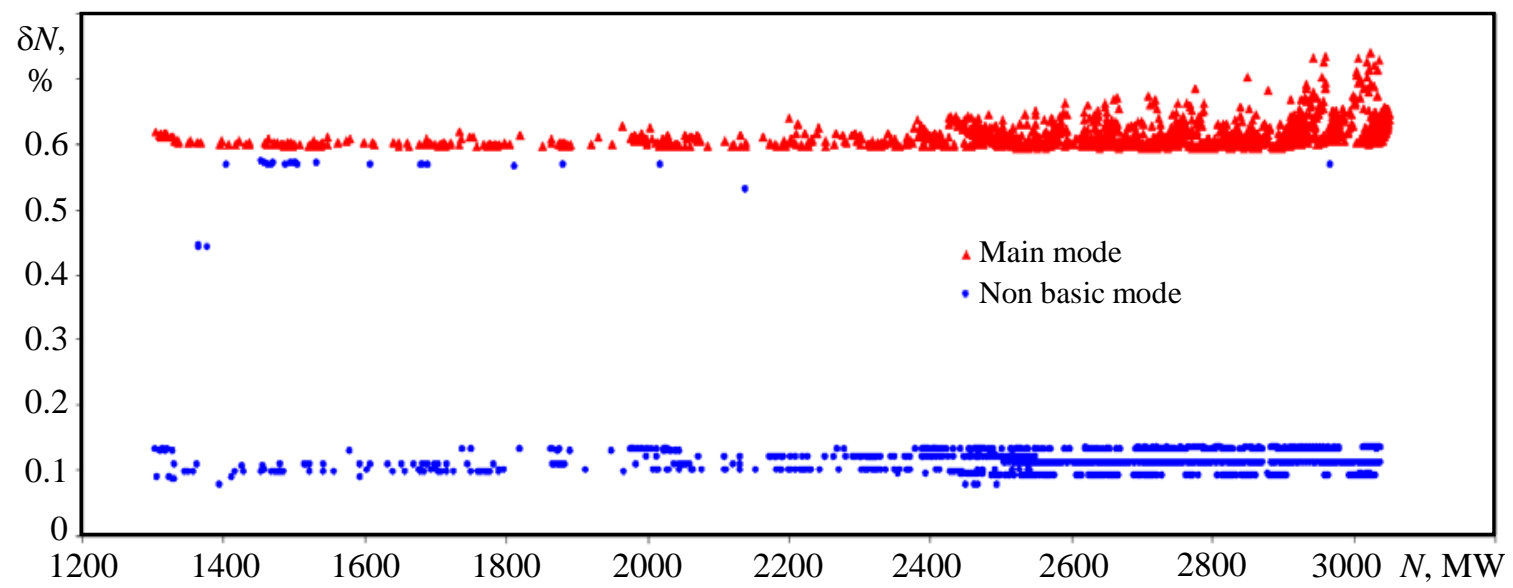

Fig. 5. Relative error of thermal power of RC according to the modified algorithm (Modification No. 1 and Modification No. 2) and optimal $k_{i}$ depending on the thermal power of $R C$ 
Modification No. 1 has a significant positive effect on the non-basic calculation algorithm, reducing the average (by the process) error of the RC AWTP. At the same time, Modification No. 1 leads to the step-wise behavior of the weighted average error, which occurs due to the cut-off of methods for estimating thermal power, which deviate from the average value by more than $2 \%$, thereby providing sensitivity to the transition process with cutting off inertial methods

The values of the coefficients $k_{i}$ to a large extent affect the error of the RC AWTP. In this case, the values of the optimal coefficients $k_{i}$ depend on the algorithm for calculating the weight coefficients $W_{i}$ and, therefore, are different for the main and minor methods of calculating the weighted average.

\section{Conclusions}

1. The minimum error of the weighted average of the thermal power of the RC is achieved when the values of the weight coefficients $W_{i}$ are inversely proportional to the square of the absolute error $\Delta N_{i}$ of the thermal power of the $i$-th $(i=1, \ldots, 5)$ method for estimating the thermal power of the RC. In this case, the error of the weighted average of the thermal power of the RC does not exceed the error of the most accurate of the averaged measurement methods. Reducing the number of averaged methods for measuring the thermal power of the RC (due to its unreliability) leads to an increase in the resultant error of the weighted average (even if the method is excluded with the maximum error).

2 . The principles for calculating the optimal $k_{i}$ values for the main and non-basic methods for calculating the weighted average are different. Therefore, when moving from one method of calculation to another, the value of the coefficient $k i$ in the constant base of the SVRK should be changed.

3. Using a type factor $\left(x_{0} / x\right)_{i}$ to calculate weights. $W_{i}$ is justified only with estimates of thermal power on the parameters of the 1st circuit.

4. When improving the cut-off algorithm of inaccurate measurements of the thermal power of the RC for the non-basic method of calculating the AWTP of the RC (Modification No. 1), this algorithm will be effectively used in the conditions of the transition process.

5. For the existing calculation algorithms (and the coefficients $k_{i}$ used for these calculations) the following values of the relative error of the weighted average value of the thermal power of the RC are obtained (not more):

- for the main method of calculating of the weighted average $1.171 \%$;

- for the non-basic method of calculating of the weighted average $2.744 \%$.

6 . In the case of the application of optimal coefficients $k_{i}$, (which are used to calculate the weighting coefficients $\mathrm{Wi}$ ), the following values of the relative error of the weighted average thermal power of the RC (for existing calculation algorithms) are obtained:

- for the main method of calculating of the weighted average $1.092 \%$;

- for the non-basic method of calculating of the weighted average $0.588 \%$.

However, it should be noted that for the non-basic method of calculating the weighted average, the use of optimal coefficients $k_{i}$ is not recommended without the modification of algorithm No. 1 , due to the complete insensitivity of the method to dynamic changes in the thermal power of the RC.

7. In the case of applying the recommendations on Modifying the calculation algorithm No. 1 and No. 2 of the weighted average (and using the optimal coefficients $k i$ ), the following values of the relative error of the weighted average thermal power of the RC were obtained (no more):

- for the main method of calculating the weighted average $0.740 \%$;

- for the non-basic method of calculating the weighted average $0.572 \%$.

\section{Литература}

1. Программное обеспечение. Подсистема физических расчетов. Руководство контролирующего физика. Описание основных алгоритмов. № ЕМКП.10114-0191 01. ЛУ СВРК-М, ЮжноУкраинская АЭС. Блок № 2, 2014. 177 с.

2. Комплексна зведена програма підвищення ефективності та надійності експлуатації енергоблоків АЕС ДП НАЕК «Енергоатом» на період 2017-2020 pр. № ПМ-Д.0.03.646-17, ДП «НАЕК «Енергоатом», 2017. - $164 \mathrm{c}$. 
3. Соколов Д.А., Ким В.В., Кузнецов В.И. Повышение мощности ВВЭР-1000. Праці Одеського політехнічного університету. 2007. Вып. 2(28). С. 60-64.

4. Mihály M., János V. Reactor Core Monitoring: Background, Theory and Practical Applications: manuscript Springer. 2017. 423 p.

5. Митин В.И., Митина О.В. Определение истинного значения величины по совокупности независимых способов измерений. Атомная энергия. 2007. Т. 103, Вып. 2. С. 139-142.

6. Малкин 3.М. О вычислении средневзвешенных значений в астрономи. Астрономический журнал. 2013. Т. 90, № 11. С. 959-964.

7. Саунин Ю.В., Добротворский А.Н., Семенихин А.В. Метод оценки весовых коэффициентов при определении средневзвешенной тепловой мощности реакторов ВВЭР. Тяжелое машиностроение. 2008. Вып. 4. С. 21-36.

8. Numerical and experimental investigation of 3D coolant temperature distribution in the hot legs of primary circuit of reactor plant with WWER-1000 / Yu. Saunin, A. Dobrotvorski, A. Semenikhin, S. Ryasny, G. Kulish, A. Abdullaev. Kerntechnik. 2015. 80(4) P. 366-372.

9. Тейлор Дж. Введение в теорию ошибок. Москва: Мир, 1985. 272 с.

\section{Referents}

1. Software. The subsystem of physical calculations. Manual controlling physics. Description of the basic algorithms. № ЕМКП.10114-01 91 01. ЛУ СВРК-М. (2014). South-Ukrainian NPP. Block № 2, 177 p.

2. The integrated program for performance of the above-mentioned operational plans of the NPP of NNEGC “Energoatom” for the period 2017-2020. № ПМ-Д.0.03.646-17 (2017). NNEGC “Energoatom”, $164 \mathrm{p}$.

3. Sokolov, D.A., Kim, V.V., \& Kuznetsov, V.I. (2007). Increasing the power of the VVER-1000. Proceedings of Odessa Polytechnic University, 2 (28), 60-64.

4. Mihály, M., \& János, V. (2017). Reactor Core Monitoring: Background, Theory and Practical Applications: manuscript Springer.

5. Mitin, V.I., \& Mitina, O.V. (2007). Determination of the true value of the value of a set of independent measurement methods. Atomic Energy, 103, 2, 139-142.

6. Malkin, Z.M. (2013). On the calculation of weighted average values in astronomy. Astronomical journal, 90, 11, 959-964.

7. Saunin, Yu.V. Dobrotvorsky, A.N., \& Semenikhin, A.V. (2008). Method for estimating weights when determining the weighted average thermal power of VVER reactors. Heavy Engineering, 4, 21-36.

8. Saunin, Yu., Dobrotvorski, A., Semenikhin, A., Ryasny, S., Kulish, G. \& Abdullaev, A. (2015). Numerical and experimental investigation of 3D coolant temperature distribution in the hot legs of primary circuit of reactor plant with WWER-1000. Kerntechnik, 80(4), 366-372.

9. Taylor, J. (1985). Introduction to the theory of errors. Moscow: Mir.

Комаров Юрій Олексійович; Komarov Yurii, ORCID: http://orcid.org/0000-0002-4696-6551

Арванінов Олексій Леонідович; Arvaninov Alexey, ORCID: https://orcid.org/0000-0002-3566-9375

Смичок Андрій Анатолійович; Smychok Andriy, ORCID: https://orcid.org/0000-0001-9143-1997 